\title{
Induction of the Phenylpropanoid Pathway by Acibenzolar-S-Methyl and Potassium Phosphite Increases Mango Resistance to Ceratocystis fimbriata Infection
}

\author{
L. Araujo, W. M. Silva Bispo, and V. S. Rios, Department of Plant Pathology; S. A. Fernandes, Department of Chemistry; and
} F. A. Rodrigues, Department of Plant Pathology, Viçosa Federal University, CEP 36570-900, Viçosa, MG, Brazil.

\begin{abstract}
Araujo, L., Bispo, W. M. S., Rios, V. S., Fernandes, S. A., and Rodrigues, F. A. 2015. Induction of the phenylpropanoid pathway by acibenzolar-smethyl and potassium phosphite increases mango resistance to Ceratocystis fimbriata infection. Plant Dis. 99:447-459.

This study used both microscopic and biochemical analyses to investigate the possible defense responses induced by acibenzolar-S-methyl (ASM) and potassium phosphite (Phi) in mango plants inoculated with Ceratocystis fimbriata. Disease development was evaluated in the stems of inoculated mango plants and these were examined using fluorescence and light microscopy. High-performance liquid chromatography (HPLC) was used to quantify secondary metabolites in the stem sections. Spraying the plants with ASM and Phi reduced internal necrosis and disease development. The ASM and Phi induced many microscopic defense responses in the stem tissues against $C$. fimbriata infection. HPLC analysis revealed that the concentrations of two alkaloids (theobromine and 7-methylxanthine) and 10 phenolic compounds

(catechin, epicatechin, epigallocatechin, gallic acid, myricetin, $p$ coumaric acid, $p$-hydroxybenzoic acid, phloridzin, sinapinic acid, and salicylhydroxamic acid) were higher in the stem tissues of plants sprayed with ASM or Phi than in inoculated control treatment. The concentrations of phenolic compounds were higher in the stem tissues of inoculated plants than in noninoculated plants, while the inverse was observed for alkaloids. Higher concentrations of secondary metabolites in the stem tissues were detected in the early stages of fungal infection, especially in plants treated with inducers. Taken together, the results from the present study clearly support the concept that the phenylpropanoid pathway in the stem tissues of mango plants infected by $C$. fimbriata can be induced by ASM and Phi.
\end{abstract}

Mango (Mangifera indica L.) is one of the most important tropical fruit crops cultivated worldwide (24). Susceptibility to diseases is a major factor that greatly decreases mango quality and yield (14). Among the diseases affecting mango production in Brazil, mango wilt, caused by the fungus Ceratocystis fimbriata Ellis \& Halst., has the greatest impact $(41,58)$. This disease bears some similarity to the wilt disease reported in Oman and Pakistan, which is caused by $C$. manginecans (56). Mango wilt causes the death of the entire tree, either a few months after the fungus penetrates the roots or more slowly if it enters through wounded branches of the canopy caused by insect vectors, and is therefore a serious concern for the growers $(41,56)$.

The acquisition of certified samplings free of $C$. fimbriata and the eradication of mango trees exhibiting disease symptoms are some of the strategies employed by the growers to reduce the yield losses caused by mango wilt $(41,58)$. In Brazil, the use of mango cultivars showing non-race-specific resistance to $C$. fimbriata infection is the most effective strategy that has been adopted by the growers to control mango wilt, mainly because chemical control was not shown to be efficient $(14,40,41,46)$. However, due to the great genetic variability of $C$. fimbriata, resistant cultivars may become susceptible in a short period of time $(40,41,46)$.

Induced resistance is an emerging control strategy that has been used to protect plants against vascular pathogens $(8,15,35,37,42)$. Induced resistance is a physiological state of enhanced defensive capacity of the plants against pathogen attack elicited by abiotic and biotic stimuli such as plant and fungal cell wall fragments, plant extracts, and synthetic chemicals, whereby the plant's basal defenses are induced against subsequent biotic challenges $(31,34,47,54,55)$.

Corresponding author: F. A. Rodrigues, E-mail: fabricio@ufv.br

Accepted for publication 21 October 2014.

http://dx.doi.org/10.1094/PDIS-08-14-0788-RE

(C) 2015 The American Phytopathological Society
This enhanced state of resistance is effective against a broad range of pathogens such as fungi, bacteria, viruses, and nematodes, as well as parasitic plants and insect herbivores $(31,34,47,54,55)$. The classic examples of inducible plant defense are systemic acquired resistance (SAR) and induced systemic resistance (ISR), which differ according to the nature of the elicitor and the host regulatory pathway involved $(31,34,47,54,55)$. In general, SAR is related to the production of pathogenesis-related proteins (PR-proteins), is induced by abiotic and biotic elicitors, and is salicylic acid dependent $(31,34,47,54,55)$. In contrast, the ISR is not related to PR-protein accumulation, is induced by biotic elicitors, and is signaled via the hormones ethylene and jasmonic acid $(31,34,47,54,55)$. In this context, some compounds such as acibenzolar-S-methyl (ASM) and potassium phosphite (Phi) have shown the potential to induce resistance in woody plants $(2,6,13,15,18,29,37-39,42,61)$.

ASM, an analog of salicylic acid, is a synthetic molecule capable of activating SAR in perennial crops $(13,28,54)$. ASM can systemically activate resistance to various pathogens in many plants by enhancing the expression of PR-proteins and increasing the concentration of secondary metabolites $(8,9,13,28,37,51,61)$.

Phi, a salt of phosphorous acid, is a systemically mobile chemical that has been used in the management of diseases caused by oomycete pathogens in many plant species $(16,18,19,22,25,50)$. Reports have also shown the potential for Phi to reduce the intensities of diseases caused by Colletotrichum gloeosporioides, Cowpea aphid-borne mosaic virus, Fusarium oxysporum, Oidium mangiferae, Passion fruit woodiness virus, Sphaerotheca pannosa, Uncinula necator, Venturia inaequalis, and Xanthomonas axonopodis $(6,7,12,29,38,39)$. Phi products are registered as supplemental soil and foliar fertilizers for annual and perennial crops $(6,7,25,29)$. Phi generally acts according to its concentration on host tissue. When the phosphite concentration is low, it induces the synthesis of host defense enzymes, phytoalexins, and phenolic compounds $(16,18,19,22,50)$. However, when the phosphite concentration is high, it acts directly on the pathogens to inhibit their growth $(16,18,19,22,50)$.

The induced synthesis of secondary metabolites in plants by previous treatment with ASM and Phi has been investigated at the 
biochemical and microscopic levels in many pathosystems such as Arabidopsis-Phytophthora palmivora $(19,22)$, cucumber-Pythium ultimum (9), tomato-F. oxysporum f.sp. radicis-lycopersici (8), and wheat-Blumeria graminis f.sp. tritici (51). Secondary metabolites are classified as alkaloids, phenolics, and terpenoids according to their biosynthetic pathways $(26,33)$. Found in many vascular plants, alkaloids are a large class of nitrogenous compounds with antimicrobial activity against many pathogens $(26,27,33,48)$. This class includes caffeine (1,3,7-trimethylxanthine), cocaine, morphine, nicotine, and theobromine compounds $(26,27,33,48)$. Many phenolics are synthesized by plants through the phenylpropanoid pathway (36). Flavonoids (apigenin, catechin, epicatechin, epigallocatechin, kaempferol, luteolin, myricetin, naringin, phloridzin, and quercetin), hydroxybenzoic acids (gallic acid, $p$-hydroxybenzoic acid, protocatechuic acid, salicylic acid, salicylhydroxamic acid, syringic acid, and vanillic acid), and hydroxycinnamic acids (coumaric acid, caffeic acid, ferulic acid, $p$-coumaric acid, and sinapinic acid) are among the most important phenolics produced by plants to cope with infection by pathogens $(17,21,36)$. Phenolics that are constitutively present in the host tissue or that are produced during the process of infection by a certain pathogen play a pivotal role in host defense (36), primarily due to their participation in cell wall lignification (8), antimicrobial activity $(17,45)$, modulation of plant hormones involved in defense signaling pathways, scavenging of reactive oxygen species (21), and reduction of the levels of the diseases severities $(8,9,45)$.

At the microscopic level, Araujo et al. $(4,5)$ demonstrated that barrier zones, the deposition of sulfur and calcium, and the accumulation of phenolic-like compounds played pivotal roles in the basal level of defense of mango cultivars against $C$. fimbriata infection. In the leaves and fruits of many mango cultivars, several antimicrobial alkaloids and phenolic compounds have been identified by highperformance liquid chromatography (HPLC) $(1,27,30,43)$, but to the best of our knowledge, these compounds have never been associated with basal or induced resistance to mango wilt.

Based on previous studies carried out by our research group, it was hypothesized that spraying a susceptible mango cultivar with ASM and Phi could induce defense responses that might counteract the deleterious effect of $C$. fimbriata. Thus, the objectives of the present study were to investigate possible defense responses induced by ASM and Phi in the susceptible mango cultivar Palmer infected with $C$. fimbriata at both microscopic and biochemical levels.

\section{Materials and Methods}

Plant material. Mango plants of the susceptible cultivar Palmer were obtained from a commercial nursery (Dona Euzébia city, Minas Gerais State, Brazil), and their rootstock was from the cv. Imbú. The 18-month-old plants, with approximately $1.5 \mathrm{~m}$ height, were transplanted into plastic pots containing $8 \mathrm{~kg}$ of soil, sand, and manure in a 2:1:1 proportion. The plants were kept in a greenhouse (temperature of $30 \pm 2{ }^{\circ} \mathrm{C}$ during the day, $10^{\circ} \mathrm{C}$ at night, and a relative humidity of $70 \pm 5 \%$ ) for 2 months before starting the experiments. The plants were watered as needed.

Application of resistance inducers. The treatments used were distilled water (control), ASM (200 mg/liter; Bion, Syngenta crop protection, São Paulo, Brazil), and Phi (1.5 ml/liter; Quimifol: 40\% $\mathrm{P}_{2} \mathrm{O}_{5}$ and $27 \% \mathrm{~K}_{2} \mathrm{O}$, Fenix Agro-Pecus, São Paulo, Brazil). The plants were sprayed separately with distilled water (inoculated control), ASM, and Phi (inducers) until runoff using a manual atomizer 5 days prior to inoculation with $C$. fimbriata. Noninoculated plants treated with inducers or water served as the control treatments (noninoculated control). Five replicates plants for each treatment at each sampling time were maintained in separate compartments during the spraying (only one spray per treatment) of the water or the inducers. One hour after being sprayed, the plants were returned to the greenhouse.

Inoculation procedure. The isolate CEBS15 of $C$. fimbriata, used to inoculate the plants, was obtained from symptomatic mango plants collected in Brejo Santo, Ceará State, Brazil. The isolate was preserved using the Castellani's method (20). Thus, for reactivation of $C$. fimbriata, plugs of a malt extract agar medium containing fungal mycelia were transferred to petri dishes containing potato dextrose agar (PDA), which were maintained in an incubator $\left(25^{\circ} \mathrm{C}\right.$ and 12-h photoperiod). After 3 days, PDA plugs containing mycelia of active colonies of $C$. fimbriata were carefully selected and transferred to new petri dishes containing the same culture medium and maintained again in incubator for 14 days.

The inoculation was performed following the methods of Araujo et al. $(4,5)$. A punch was used to remove bark disks (10-mm diameter and 2-mm height) from the stems (approximately 20-mm diameter) of five plants designated for each treatment. The bark disks were removed approximately $5 \mathrm{~cm}$ above the graft scar. A plug (10-mm diameter), removed from the middle portion of each PDA plate obtained from 14-day-old colonies of $C$. fimbriata, was placed in the wound. Each wound containing the mycelial plug was carefully covered with a piece of moistened cotton and wrapped with Parafilm to maintain adequate moisture to allow fungal infection. Wounds on the stems of plants treated with inducers or water that received plugs of PDA medium alone served as the control treatments (noninoculated control).

Disease assessment. The disease progress in the stem tissues was evaluated at 7, 14, and 21 days after inoculation (dai). The symptoms of internal necrosis in both longitudinal and transverse stem sections caused by $C$. fimbriata infection were photographed using a stereomicroscope (Stemi 2000-C, Carl Zeiss, Germany) coupled to a digital camera (PowerShot A640, Canon).

The upward, downward, and radial colonization of the stem tissues by the hyphae of $C$. fimbriata was accomplished by measuring the length (in $\mathrm{cm}$ ) of internal necrotic tissue using an electronic digital caliper (Neiko 01407A, Stainless Steel, Mandaluyong, Philippines) according to Araujo et al. (4). Upward relative lesion length (URLL) and downward relative lesion length (DRLL) were expressed as the ratio between the length from the graft scar to the top of the stem (LGST) and the lesion length (LL) taken from the same area (upward and downward) beginning at the inoculation point. The following formula: URLL or DRLL $=$ LL $\times 100 / L G S T$ was used. The stem of each plant was standardized to a length of $20 \mathrm{~cm}$ (distance from the graft scar to the top of the stem). The radial fungal colonization (RFC) was determined as the length of the necrotic tissue in relation to the total stem diameter $\times 100$.

Data from URLL, DRLL, and RFC were used, respectively, to calculate the area under the upward relative lesion length progress curve (AUURLLPC), area under the downward relative lesion length progress curve (AUDRLLPC), and area under the radial fungal colonization progress curve (AURFCPC) according to Shaner and Finney (49).

Processing the infected stem tissues for microscopic studies. Approximately 25 to 30 transverse and longitudinal stem sections (10 $\mathrm{mm}$ thick) from four inoculated plants for each treatment (distilled water [control], ASM, or Phi) were obtained from $3 \mathrm{~cm}$ below and above the inoculation point at 7,14 , and 21 dai according to Araujo et al. $(4,5)$. The stem sections were carefully transferred to glass vials containing $10 \mathrm{ml}$ of a fixative composed of $3 \%(\mathrm{v} / \mathrm{v})$ glutaraldehyde and $2 \%$ paraformaldehyde $(\mathrm{v} / \mathrm{v})$ in $0.1 \mathrm{M}$ sodium cacodylate buffer ( $\mathrm{pH}$ 7.2). The vials were then covered with aluminum foil and stored at $4^{\circ} \mathrm{C}$ for 2 months until being used for the fluorescence and light microscopy studies.

Fluorescence microscopy. A total of four transverse stem sections from the inoculated plants sprayed with distilled water, ASM, or Phi were washed three times with distilled water and mounted on glass slides with two drops of a glycerine/water solution $(2: 8, \mathrm{v} / \mathrm{v})$ according to Araujo et al. (5). The autofluorescence of the stem sections was evaluated using an fluorescent Carl Zeiss Axio Imager A1 microscope (Carl Zeiss, Jena, Thuringia, Germany) with the Zeiss filter sets 01 (UV; $365 \mathrm{~nm}$ excitation, $395 \mathrm{~nm}$ beam splitter, and $397 \mathrm{~nm}$ emission) and 05 (blue; 395-400 nm excitation, $460 \mathrm{~nm}$ beam splitter, and $470 \mathrm{~nm}$ emission). Autofluorescence was used because secondary metabolites can be detected by examining autofluorescence because phenolics and related polymers such as lignin absorb short-wavelength light in 
the ultraviolet and near-blue range and emit longer wavelengths of visible light $(3,5,10,11,23,44)$. The images were acquired digitally (Axio Cam HR, Carl Zeiss) with a Carl Zeiss Axio Imager A1 microscope and further processed with Axion Vision 4.8.1 software.

Processing infected stem tissues for light microscopy. The samples were removed from glass vials containing fixative and washed with $0.1 \mathrm{M}$ sodium cacodylate buffer, subsequently dehydrated through a graded alcohol series $(10,30,50,70,85,95$, and $100 \%)$, and embedded in methacrylate resin (Historesin, Leica, Nussloch, Heidelberg, Germany) according to Araujo et al. (4). During the preinfiltration and infiltration steps, the samples were placed in a vacuum chamber for $2 \mathrm{~h}$ both in the morning and in the afternoon for 3 weeks to allow better resin infiltration into the stem tissue. The samples were stored at $4^{\circ} \mathrm{C}$ after each vacuum procedure. A total of six blocks of resin, each containing two stem fragments, were obtained for each treatment at each sampling time. A total of 36 longitudinal and
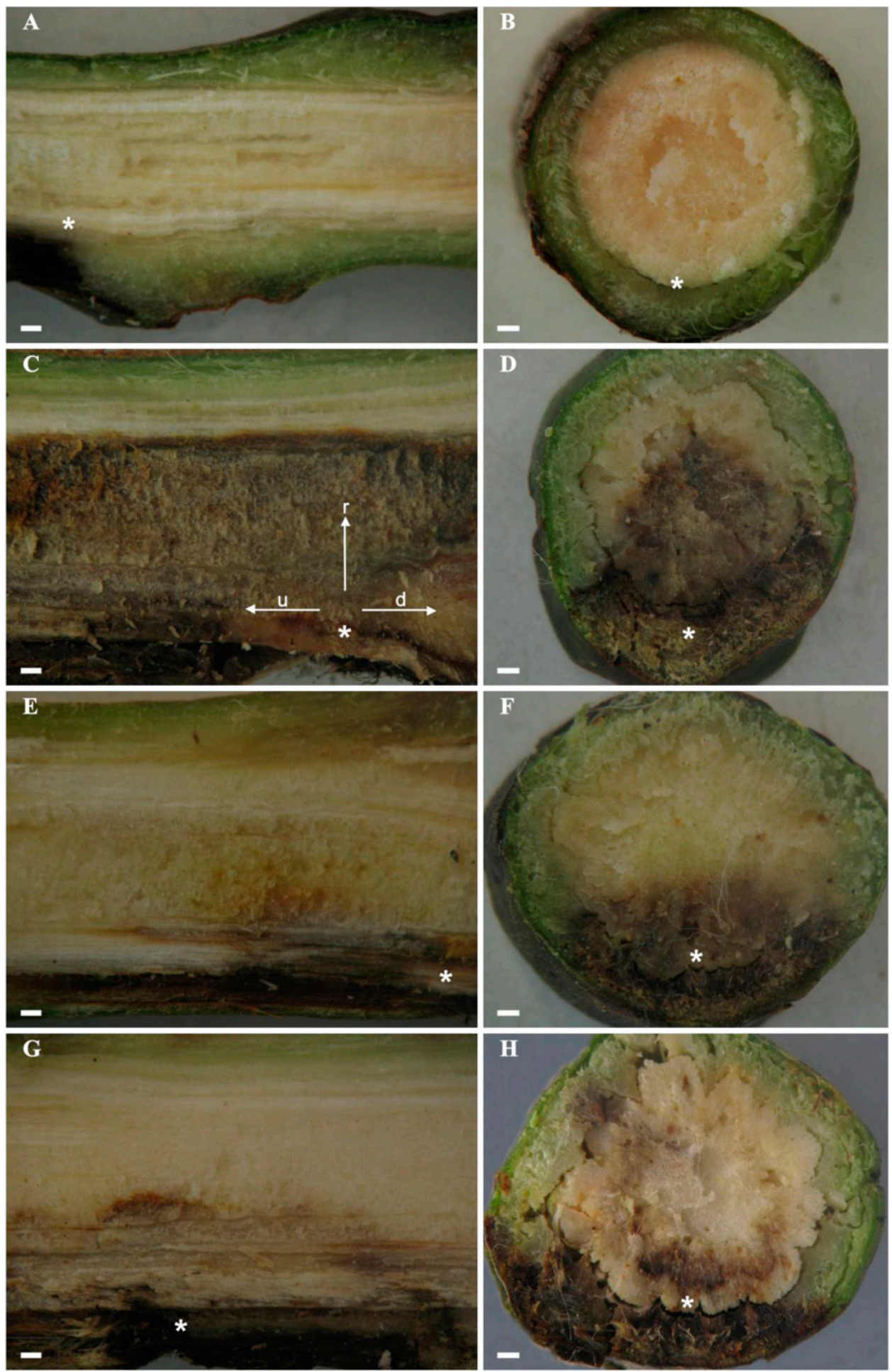

Fig. 1. Stem sections of noninoculated mango plants (A and B). Internal necrosis caused by Ceratocystis fimbriata infection in longitudinal (C, E, and $\mathbf{G})$ and transverse (D, F, and H) stem sections of plants previously sprayed with distilled water (control plants; $\mathbf{C}$ and $\mathbf{D}$ ), acibenzolar-S-methyl (E and F), and potassium phosphite ( $\mathbf{G}$ and $\mathbf{H}$ ) at 21 days after inoculation. Asterisks $\left({ }^{*}\right)$ indicate the stem region where the wound was made and from which the upward $(\mathrm{u})$, downward (d), and radial (r) $C$. fimbriata colonization was measured as detailed in $\mathrm{C}$. 
transverse serial sections ( $2 \mu \mathrm{m}$ thick) were cut from each block using a Leica RM 2245 rotary microtome (Leica Microsystems, Nussloch, Germany), which were randomly divided into three glass slides and stained with $1 \%$ toluidine blue in $2 \%$ sodium borate for $5 \mathrm{~min}$. Toluidine blue is a metachromatic dye commonly used for staining plant tissue sections (57). Typical host defense such as accumulation of phenolic compounds in plants to prevent fungal colonization has been observed by staining of tissue sections with toluidine blue $(4,8,9,45)$. When the specimen samples stained with toluidine blue are viewed under the microscope, distinct different cell components produce different colors: DNA is bluish-green, RNA is violet, the middle lamella is red, nonlignified cell walls and soluble phenolic compounds are red-violet, blue violet, blue, or purple, and polymerized phenolics such as lignin are green or bluish-green (57). The images of the details regarding fungal infection and host defense responses were acquired digitally (Axio Cam HR, Carl Zeiss) in bright-field mode and further processed as described above.

Processing of stem tissues for the analysis of alkaloids and phenolic compounds. Longitudinal stem sections (10 cm length) with inoculation point centered within the sample were obtained from five plants sprayed with distilled water (inoculated control), ASM, or Phi at 7, 14, and 21 dai. Sections taken from the stems of noninoculated plants treated and not treated with inducers served as the control treatments (noninoculated control). The stem sections were carefully covered with aluminum foil, placed into plastic bags, frozen in liquid nitrogen, and stored at $-80^{\circ} \mathrm{C}$ (up to 1 month) until the extraction of the alkaloids and phenolic compounds.

Chemicals. Methanol and the standards caffeic acid, catechin, chlorogenic acid, epicatechin, epigallocatechin, gallic acid, kaempferol, myricetin, $p$-coumaric acid, $p$-hydroxybenzoic acid, phloridizin, protocatechuic acid, salicylhydroxamic acid, sinapinic acid, syringic acid, theobromine, xanthine, 3-methylxanthine, and 7-methylxanthine (Sigma-Aldrich, São Paulo, SP, Brazil) were used to quantify individual alkaloids and phenolics. Purified water was generated from a Millipore Direct-Q ultrapure water system (Millipore, Billerica, MA). Standards were dissolved in methanol/water solution $(80: 20, \mathrm{v} / \mathrm{v})$.

Extraction of alkaloids and phenolic compounds. The stem sections were lyophilized using a freeze-dryer (maintained at $-62 \pm 2{ }^{\circ} \mathrm{C}$ ) model L101 (LIOTOP, Liobras, São Carlos, SP, Brazil) for $72 \mathrm{~h}$ and ground in a ball mill (TECNAL TE 350, Piracicaba, SP, Brazil) for 4 min. The extraction of secondary metabolites from the stem sections was performed as described by Lisec et al. (32) and Tohge and Fernie (52) with some modifications. The fine powder $(50 \mathrm{mg})$ of each lyophilized material was transferred to microcentrifuge tubes and extracted with $1.8 \mathrm{ml}$ of a methanol/water solution $(80: 20, \mathrm{v} / \mathrm{v})$. The suspension was incubated for $30 \mathrm{~min}$ at $30^{\circ} \mathrm{C}$ with constant shaking (950 rpm; Thermomixer Comfort, Eppendorf, Hamburg, Germany). The extracts from the stem tissues were centrifuged at $11,000 \times g$ for $10 \mathrm{~min}$ at $4^{\circ} \mathrm{C}$, and the supernatants were transferred to new microcentrifuge tubes and stored at $-80^{\circ} \mathrm{C}$ until the determination of the alkaloids and phenolic compounds.

Determination and quantitation of alkaloids and phenolic compounds. The compounds present in the supernatant of each sample were analyzed using HPLC with a Thermo Scientific Accela LC Systems (Accela PDA detector, Accela autosampler, and Accela Pump) (Thermo Fisher Scientific, Austin, TX) that was fitted with a C18 reverse-phase column (RP-18 Li-Chrospher, $5 \mu \mathrm{m}, 150 \times 4.6$ $\mathrm{mm}$, Supelco, Bellefonte, PA). The elution solvents were: A (aqueous $0.01 \mathrm{M}$ phosphoric acid) and $\mathrm{B}(100 \%$ methanol). The gradient operation was as follows: 85(A)-15(B)\% over 2 min, 75(A)-25(B)\% over 3 min, 70(A)-30(B)\% over 5 min, 65(A)-35(B)\% over 5 min, 50 (A)-50(B) $\%$ over $5 \mathrm{~min}, 40(\mathrm{~A})-60(\mathrm{~B}) \%$ over $10 \mathrm{~min}, 20(\mathrm{~A})-80(\mathrm{~B}) \%$ over $5 \mathrm{~min}, 00(\mathrm{~A})-100(\mathrm{~B}) \%$ over $5 \mathrm{~min}, 95(\mathrm{~A})-5(\mathrm{~B}) \%$ over $10 \mathrm{~min}$, 85(A)-15(B)\% over $15 \mathrm{~min}$, and 100(A)-00(B)\% over $5 \mathrm{~min}$. A total of $5 \mu \mathrm{l}$ of each extract was injected into the column at a flow rate of $0.5 \mathrm{ml} / \mathrm{min}$. The eluted compounds were monitored at 280 and $320 \mathrm{~nm}$ and their identifications were achieved by comparing the retention times and spectra as well as by cochromatography. The concentration of each alkaloid and phenolic compound was calculated from the peak areas of the sample and the corresponding standard.
The concentration of each alkaloid and phenolic compound was expressed as $\mu \mathrm{g} / 100 \mathrm{mg}$ dry weight of stem tissue.

Experimental design and data analysis. A $3 \times 2 \times 3$ factorial experiment consisting of the inducers (ASM and Phi) and distilled water (control treatment), plant inoculation (noninoculated or inoculated plants), and three evaluation times (7, 14, and 21 dai) was arranged in a completely randomized design with five replicates. Each replicate consisted of a plastic plot containing one mango plant. The experiment was repeated once. Data with zero values were transformed to the square root of $\times$ before statistical analysis. Data were subjected to normality, analyzed by an analysis of variance (ANOVA), and comparisons of the treatment means were performed with Tukey's test $(P \leq 0.05)$ using SAS (Release 8.02 Level 02 M0 for Windows, SAS Institute, Inc., 1989, Cary, NC).

\section{Results}

Disease assessments. A discrete internal necrosis at the wound point, without any progress in the subsequent evaluation times, was observed in the stem tissues of the noninoculated plants (Fig. $1 \mathrm{~A}$ and $\mathrm{B})$. The stem tissues obtained from plants sprayed with ASM (Fig. 1E and F) or Phi (Fig. 1G and H) and inoculated with C. fimbriata showed less internal necrosis compared with the stem tissues obtained from the control plants (Fig. 1C and D). The ASM treatment reduced AUURLLPC, AUDRLLPC, and AURFCPC significantly, by 152, 24, and 33\%, respectively, compared with the control treatment (Table 1). There were significant decreases of 40 and $15 \%$ for AUURLLPC and AURFCPC, respectively, for the Phi treatment compared with the control treatment (Table 1).

Fluorescence microscopy. In the stem tissues from the plants sprayed with ASM or Phi, the parenchyma cells, xylem vessels, and pith parenchyma proximal to the internal necrotic areas exhibited strong autofluorescence using blue (Fig. 2B1, C1, E1, F1, H1, and I1) and UV (Fig. 2B2, C2, E2, F2, H2, and I2) filter sets at 7 (Fig. 2B1, B2, C1, and C2), 14 (Fig. 2E1, E2, F1, and F2), and 21 (Fig. 2H1, H2, I1, and I2) dai. The stem tissues of the plants from the inoculated control treatment exhibited weak autofluorescence regardless of the evaluation time (Fig. 2A1, A2, D1, D2, G1, and G2).

Light microscope observations. Colonization of the stem tissues by $\mathrm{C}$. fimbriata in plants treated and not treated with inducers. An examination of several longitudinal and transverse stem tissue sections at 21 dai using a light microscope confirmed the visual differences observed in the pattern of the internal stem necrosis among the treatments. The stem tissues of the plants sprayed with distilled water were profoundly colonized by $C$. fimbriata starting from the collenchyma and extending in the directions of the cortical parenchyma, xylem vessels, and pith parenchyma (Fig. 3). By contrast, plants sprayed with ASM or Phi showed localized defense responses that probably contributed to decrease the upward, downward, and radial fungal growth (Figs. 4 and 5).

Colonization of collenchymas. The fungal hyphae that colonized the collenchyma cells were frequently surrounded by phenolic-like compounds that stained densely with toluidine blue (Figs. 3A, 4A,

Table 1. Area under upward relative lesion length progress curve (AUURLLPC), area under downward relative lesion length progress curve (AUDRLLPC), and area under radial fungal colonization progress curve (AURFCPC) in the stem tissues of mango plants sprayed with distilled water (control), acibenzolarS-methyl (ASM), or potassium phosphite (Phi) and inoculated with Ceratocystis fimbriata

\begin{tabular}{lccc}
\hline Treatments & AUURLLPC & AUDRLLPC & AURFCPC \\
\hline Control & $354.9 \mathrm{a}$ & $202.7 \mathrm{a}$ & $746.1 \mathrm{a}$ \\
ASM & $141.4 \mathrm{c}$ & $163.8 \mathrm{~b}$ & $563.1 \mathrm{c}$ \\
Phi & $253.1 \mathrm{~b}$ & $191.8 \mathrm{ab}$ & $646.9 \mathrm{~b}$ \\
$F$ values $^{\mathrm{z}}$ & $104.36^{* *}$ & $6.23^{*}$ & $69.98^{* *}$ \\
\hline
\end{tabular}

y Means within each column followed by the same letter are not significantly different according to the Tukey's test.

${ }^{\mathrm{z}}$ Levels of probability: $*=0.05$, and $* *=0.01$. The upward, downward, and radial colonization of the stem tissues by the hyphae of $C$. fimbriata was accomplished by measuring the length (in $\mathrm{cm}$ ) of internal necrotic tissue. 
and 5A). Many fungal hyphae, which appeared to be dead (empty), were observed in the collenchyma cells of the stem tissues obtained from the plants sprayed with ASM or Phi (Figs. 4A and 5A).

Colonization of cortical parenchyma. The hyphae of $C$. fimbriata apparently grew without any impedance in the cortical parenchyma of the stem tissues of plants from the control treatment (Fig. 3B).
In some cells, small amounts of phenolic-like compounds were deposited around the fungal hyphae (Fig. 3B). In contrast, in the plants sprayed with ASM or Phi, most of the cells of the cortical parenchyma that were colonized by fungal hyphae reacted strongly to fungal invasion by the deposition of phenolic-like compounds (Figs. 4B and $5 \mathrm{~B}$ ). In these cells, the fungal hyphae frequently appeared to be
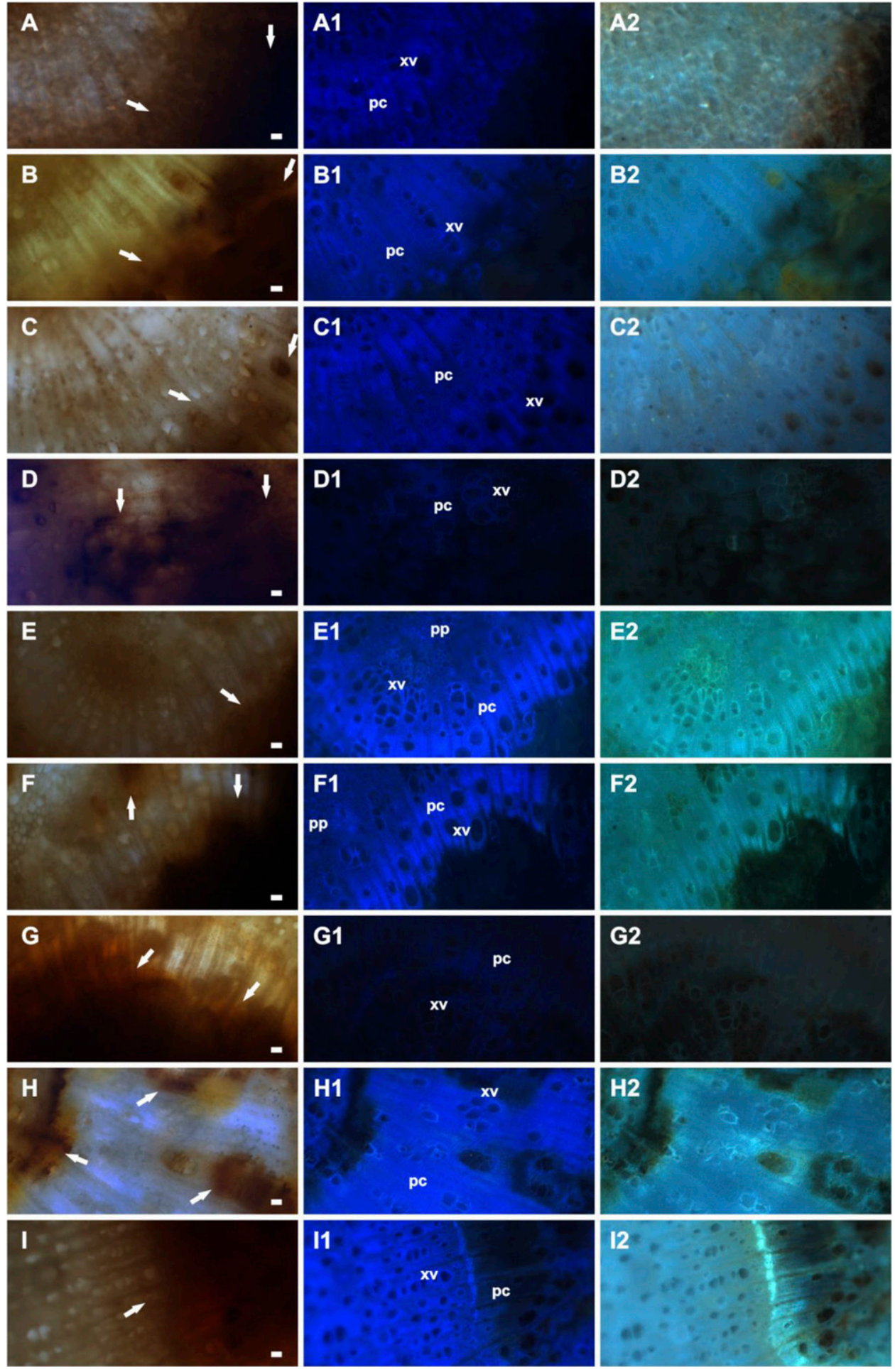

Fig. 2. Light (A, B, C, D, E, F, G, H, and I) and corresponding fluorescence (A1, A2, B1, B2, C1, C2, D1, D2, E1, E2, F1, F2, G1, G2, H1, H2, I1, and I2) microscopy images in transverse stem sections of mango plants sprayed with distilled water (A, A1, A2, D, D1, D2, G, G1, and G2), acibenzolar-S-methyl (B, B1, B2, E, E1, E2, H, H1, and H2), and potassium phosphite (C, C1, C2, F, F1, F2, I, I1 and I2) at 7 (A, A1, A2, B, B1, B2, C, C1, and C2), 14 (D, D1, D2, E, E1, E2, F, F1, and F2), and 21 (G, G1, G2, H, H1, H2, I, I1, and 12) days after inoculation (dai) with Ceratocystis fimbriata. Arrows in $A, B, C, D, E, F, G, H$, and I indicate the internal necrosis caused by $C$. fimbriata infection in transverse stem sections. Autofluorescence in transverse stem sections was recorded when observed with blue ( 395 to $400 \mathrm{~nm}$ excitation; A1, B1, C1, D1, E1, F1, G1, H1, and I1) and UV ( $365 \mathrm{~nm}$ excitation; A2, B2, C2, D2, E2, F2, G2, H2, and I2) filter sets. Parenchyma cells (pc), pith parenchyma (pp), and xylem vessels (xv). Scale bars $=50 \mu \mathrm{m}$. 
dead (empty), and were encrusted with phenolic-like compounds (Figs. 4B and 5B).

Colonization of xylem vessels. In the stem tissues of the plants from the control treatment, few parenchyma cells adjacent to the xylem vessels reacted to the fungal invasion (Fig. 3C, D, E, F, and G).
Fungal hyphae reached the xylem vessels and stimulated intense formation of polysaccharide gels and tyloses (Fig. 3C, D, E, F, and G). In contrast, in the plants sprayed with ASM or Phi, many cells of the medullary radius and parenchyma cells adjacent to the xylem vessels accumulated phenolic-like compounds that appeared to act as
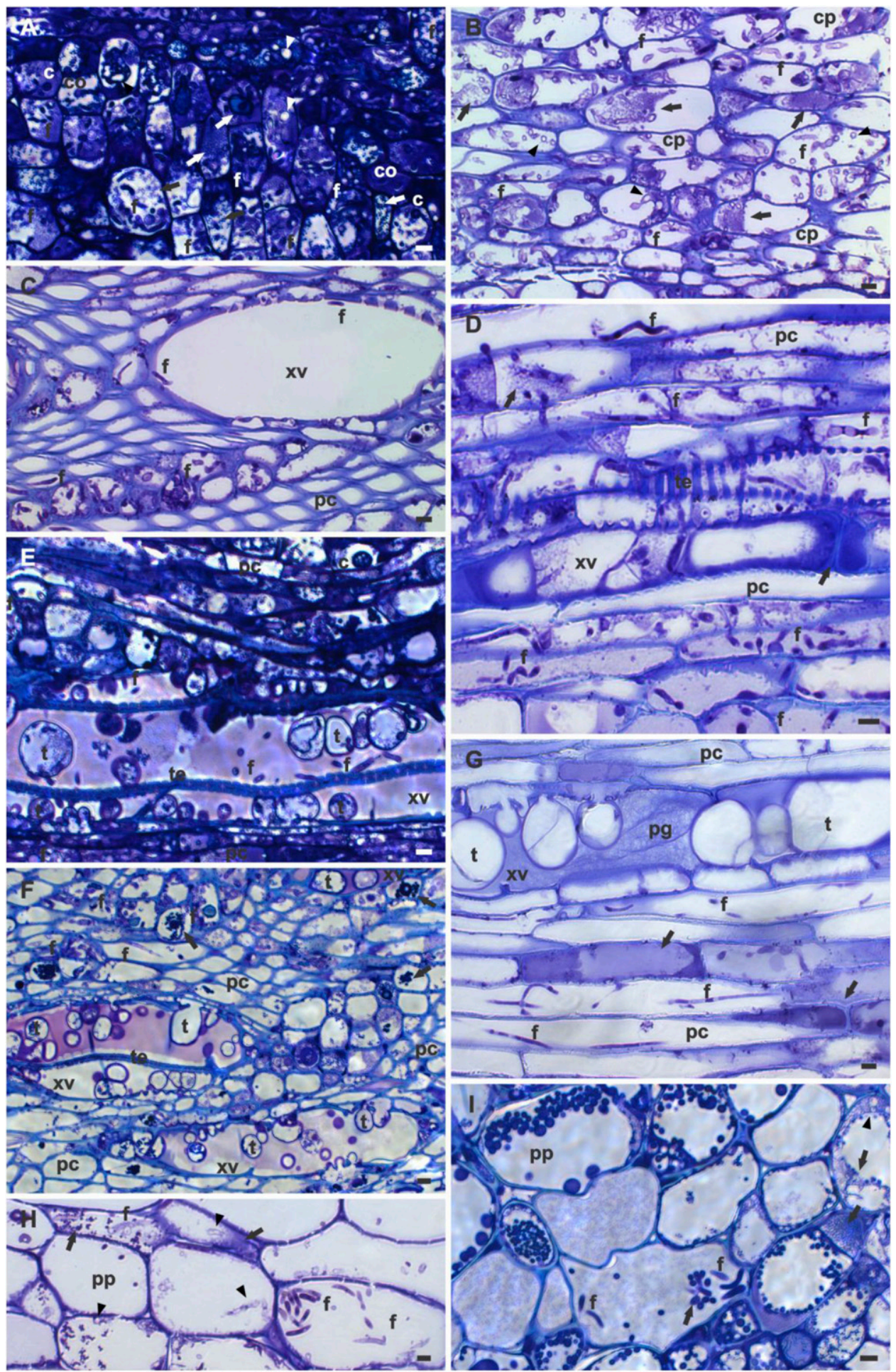

Fig. 3. Light micrographs of longitudinal (A, D, E, G, and H) and transverse (B, C, F, and I) stem tissues 21 days after inoculation with Ceratocystis fimbriata in mango plants previously sprayed with distilled water. A, Hyphae and chlamydospores (aleurioconidia) of $C$. fimbriata grew abundantly in the collenchyma cells. B, Fungal hyphae massively colonized the cortical parenchyma. C, D, E, and F, The fungus reached the xylem vessels stimulating tylosis formation. G, Xylem vessels were obstructed by intense deposition of polysaccharide gels and tyloses. $\mathbf{H}$ and I, Hyphae of $\mathbf{C}$. fimbriata colonized the pith parenchyma. A to I, Some collenchyma, parenchyma, and pith parenchyma cells that reacted to fungal invasion stained dark blue or purple (arrow) whereas others accumulated amorphous granular material around fungal hyphae (arrow). Some fungal hyphae appeared dead (arrowheads). Chlamydospores (c), collenchyma (co), cortical parenchyma (cp), fungal hyphae (f), parenchyma cells (pc), pith parenchyma $(\mathrm{pp})$, polysaccharide gels (pg), tracheal elements (te), tylosis (t), and xylem vessels (xv). Scale bars: $10 \mu \mathrm{m}$. 
antifungal barrier to $C$. fimbriata colonization (Figs. 4C, D, E, F, and $\mathrm{G} ; 5 \mathrm{C}, \mathrm{D}, \mathrm{E}, \mathrm{F}$, and G). The xylem vessels were frequently obstructed by large tyloses that stained dark blue or purple, indicating the presence of phenolic-like compounds (Figs. 4C, D, E, F, and G; 5C, D, E, $\mathrm{F}$, and $\mathrm{G})$. Furthermore, the fungal hyphae were rarely observed in the xylem vessels from stem tissues of plants sprayed with ASM or Phi (Figs. 4C, D, E, F, and G; 5C, D, E, F, and G).

Colonization of pith parenchyma. Fungal hyphae extensively colonized the pith parenchyma in the stem tissues of the plants from the control treatment (Fig. 3H and I). Some cells reacted to the fungal

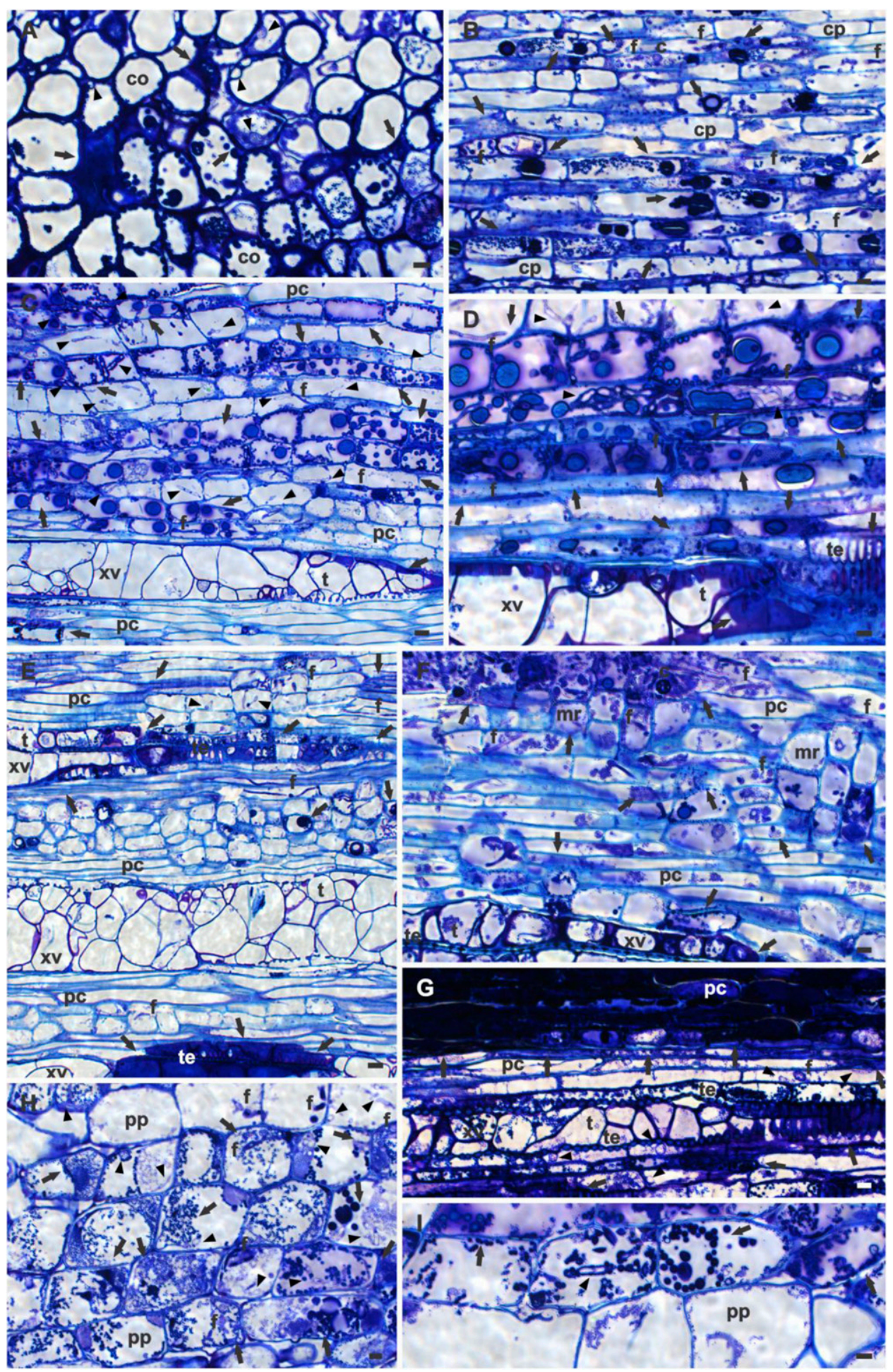

Fig. 4. Light micrographs of longitudinal stem tissues 21 days after inoculation with Ceratocystis fimbriata in mango plants previously sprayed with acibenzolar-S-methyl. A, Hyphae of C. fimbriata in the collenchyma cells were scarce. B, Hyphae and chlamydospores (aleurioconidia) of C. fimbriata occasionally grew in the cortical parenchyma. C, D, E, F, and G, Many cells of the medullary radius and parenchyma cells adjacent to the xylem vessels accumulated phenolic-like compounds (arrow). Xylem vessels were occasionally colonized by fungal hyphae and frequently stained as dark blue or purple (arrow). They also contained many large tyloses. $\mathbf{H}$ and $\mathbf{I}$, Hyphae of $\mathrm{C}$. fimbriata occasionally colonized pith parenchyma. A to I, Frequently, collenchyma, parenchyma, and pith parenchyma cells reacted strongly to fungal invasion by staining dark blue or purple (arrow) whereas others accumulated amorphous granular material around fungal hyphae (arrow) indicating the presence of phenolic-like compounds. Many fungal hyphae appeared dead (arrowheads). Chlamydospores (c), collenchyma (co), cortical parenchyma (cp), fungal hyphae (f), medullary radius (mr), parenchyma cells (pc), pith parenchyma (pp), tracheal elements (te), tylosis (t), and xylem vessels (xv). Scale bars: $10 \mu \mathrm{m}(\mathrm{A}, \mathrm{B}, \mathrm{D}, \mathrm{F}, \mathrm{G}, \mathrm{H}$, and $\mathrm{I})$ and $20 \mu \mathrm{m}(\mathrm{C}$ and $\mathrm{E})$. 
invasion by accumulating phenolic-like compounds (Fig. $3 \mathrm{H}$ and I). In contrast, in the plants sprayed with ASM or Phi, fungal hyphae scarcely colonized the pith parenchyma (Figs. $4 \mathrm{H}$ and I; $5 \mathrm{H}$ and I). Most of the cells reacted to the $C$. fimbriata infection by accumulating phenolic-like compounds that surrounded many fungal hyphae, which sometimes appeared dead (empty) (Figs. 4H and I; 5H and I).
Quantification of alkaloids and phenolic compounds. The factors of inducer treatment, plant inoculation, and evaluation times and their interactions were significant for the concentrations of catechin, epicatechin, epigallocatechin, gallic acid, myricetin, $p$-coumaric acid, $p$-hydroxybenzoic acid, phloridzin, salicylhydroxamic acid, sinapinic acid, theobromine, and 7-methylxanthine (Table 2). The
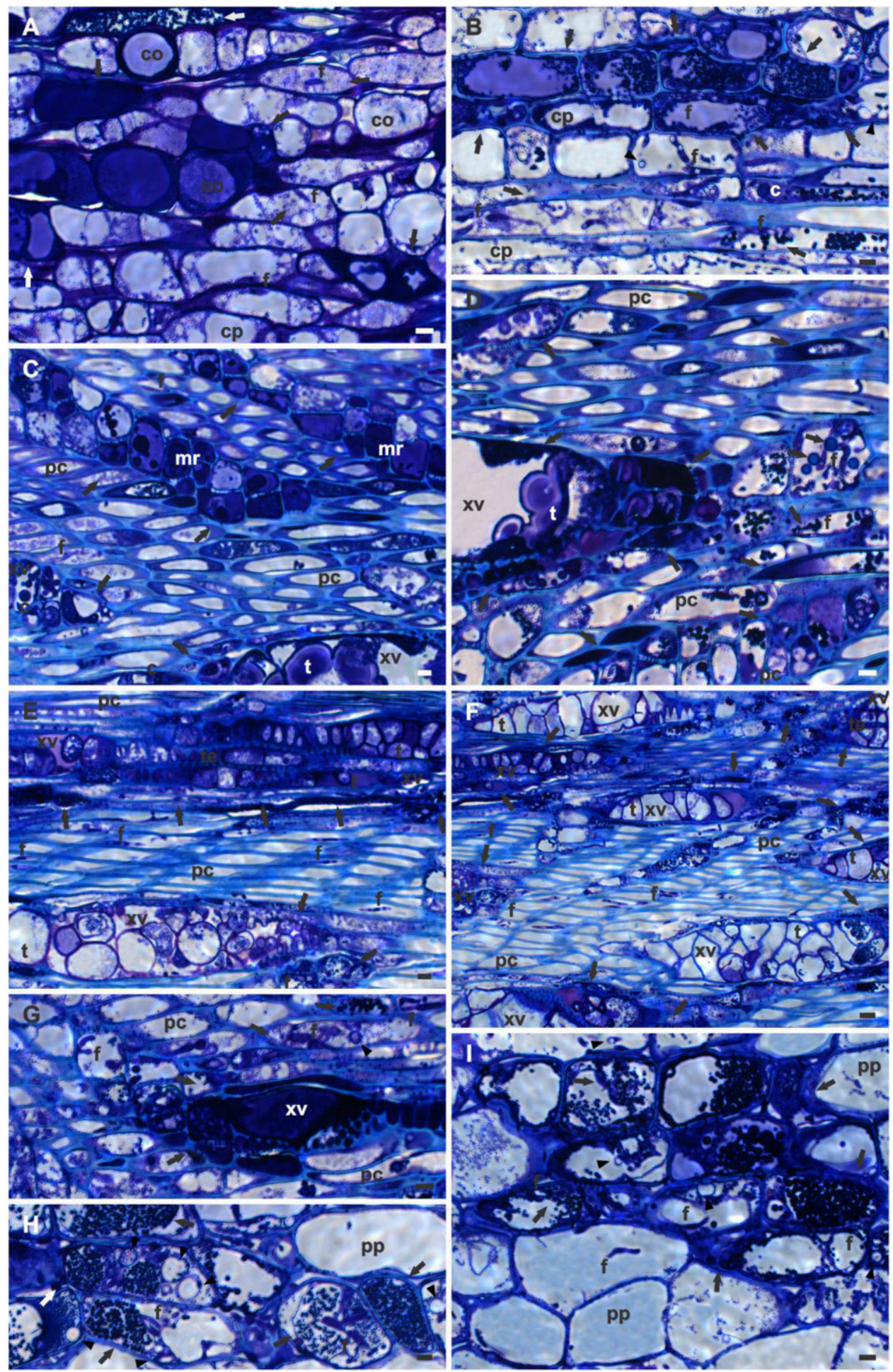

Fig. 5. Light micrographs of longitudinal (A, B, E, F, G, H, and I) and transverse ( $C$ and $\mathrm{D}$ ) stem tissues 21 days after inoculation with Ceratocystis fimbriata in mango plants previously sprayed with potassium phosphite. A, Hyphae of $C$. fimbriata in the collenchyma cells were scarce. B, Hyphae and chlamydospores (aleurioconidia) of $C$. fimbriata scarcely grew in the cortical parenchyma. C, D, E, F, and G, Many cells of the medullary radius and parenchyma cells adjacent to the xylem vessels accumulated phenolic-like compounds (arrow). Xylem vessels were occasionally colonized by fungal hyphae and frequently stained as dark blue or purple (arrow). They also contained many large tyloses. $\mathbf{H}$ and $\mathbf{I}, \mathrm{Hyphae}$ of $\mathrm{C}$. fimbriata scarcely colonized the pith parenchyma. A to I, Frequently, collenchyma, parenchyma, and pith parenchyma cells reacted strongly to fungal invasion by staining dark blue or purple (arrow) whereas others accumulated amorphous granular material around fungal hyphae (arrow) indicating the presence of phenolic-like compounds. Many fungal hyphae appeared dead (arrowheads). Chlamydospores (c), collenchyma (co), cortical parenchyma (cp), fungal hyphae ( $f$ ), medullary radius (mr), parenchyma cells $(p c)$, pith parenchyma (pp), tracheal elements (te), tylosis (t), and xylem vessels (xv). Scale bars: $10 \mu \mathrm{m}(\mathrm{A}, \mathrm{B}, \mathrm{C}, \mathrm{D}, \mathrm{E}, \mathrm{G}, \mathrm{H}$, and I) and $20 \mu \mathrm{m}(\mathrm{F})$. 
factors of evaluation times and the inducer treatment $\times$ plant inoculation interaction were not significant only for the concentrations of theobromine and salicylhydroxamic acid, respectively (Table 2). The decomposition of the interactions among the studied factors were described for alkaloids, hydroxycinnamic acids, hydroxybenzoic acids, and flavonoids separately.

Alkaloids. The concentration of theobromine in the stem tissues of the inoculated plants sprayed with ASM was higher than those in the plants from the control treatment at 21 dai (Table 3). Stem tissue of inoculated plants sprayed with Phi contained more theobromine in comparison with the control treatment at 7 and 14 dai (Table 3). The concentration of 7-methylxanthine in the stem tissues of the inoculated plants sprayed with Phi increased in comparison with the control treatment at 14 dai (Table 3).

The concentrations of theobromine and 7-methylxanthine were higher in the stem tissues of the noninoculated plants than in the stem tissues of the inoculated plants, regardless of the treatment (Table 3). Higher concentrations of theobromine and 7-methylxanthine were detected at 7 and 14 dai in the stem tissues of noninoculated or inoculated plants sprayed with water, ASM, or Phi (Table 3).

Hydroxycinnamic acids. The concentration of $p$-coumaric acid in the stem tissues of the inoculated plants sprayed with ASM and Phi was higher than those in the plants from the control treatment at 7 dai (Table 4). Stem tissue of inoculated plants sprayed with ASM contained more sinapinic acid in comparison with the control treatment at 7 and 21 dai (Table 4). The concentration of sinapinic acid in the stem tissues of the inoculated plants sprayed with Phi increased in comparison with the control treatment at 21 dai (Table 4).

The concentrations of $p$-coumaric acid and sinapinic acid were higher in the stem tissues of the inoculated plants than in the stem tissues of the noninoculated plants, regardless of the treatment (Table 4). Higher concentrations of $p$-coumaric acid and sinapinic acid were detected at 7 dai in the stem tissues of the noninoculated or inoculated plants sprayed with water, ASM, or Phi (Table 4).

Hydroxybenzoic acids. The concentration of gallic acid in the stem tissues of the inoculated plants sprayed with ASM and Phi was higher than those of the plants from the control treatment at 21 dai (Table 5). Stem tissue of inoculated plants sprayed with ASM and Phi contained more $p$-hydroxybenzoic acid in comparison with the control treatment at 21 dai (Table 5). The concentration of salicylhydroxamic acid in the stem tissues of the inoculated plants sprayed with ASM increased in comparison with the control treatment at 7 and 21 dai (Table 5). The concentration of salicylhydroxamic acid was greater for the inoculated plants sprayed with Phi than the control treatment at 21 dai (Table 5).

Regardless of the treatment, the concentrations of $p$-hydroxybenzoic acid and salicylhydroxamic acid were higher in the stem tissues of the inoculated plants than in the stem tissues of the noninoculated plants, while the inverse was observed for gallic acid (Table 5). Higher concentrations of gallic acid, $p$-hydroxybenzoic acid, and salicylhydroxamic acid were detected at 14 and 21 dai in the stem tissues of the noninoculated or inoculated plants sprayed with water, ASM, or Phi (Table 5).

Flavonoids. The concentration of catechin in the stem tissues of the inoculated plants sprayed with ASM or Phi was higher than those of the plants from the control treatment at 21 dai (Table 6). Stem tissue of inoculated plants sprayed with ASM contained more epicatechin in comparison with the control treatment at 7 and 21 dai (Table 6). The concentration of epigallocatechin in the stem tissues of the inoculated plants sprayed with ASM and Phi increased in comparison with the control treatment at 21 dai (Table 6). The concentrations of myricetin and phloridzin were greater for the inoculated plants sprayed with ASM and Phi than the control treatment at 14 and 21 dai (Table 6).

Table 2. Analysis of variance of the inducer treatment (IT), plant inoculation (PI), and evaluation time (ET) on the variables concentrations of theobromine (TBR), 7-methylxanthine (7-MX), p-coumaric acid (PCA), sinapinic acid (SA), gallic acid (GA), p-hydroxybenzoic acid (PHB), salicylhydroxamic acid (SHAM), catechin (CAT), epicatechin (EC), epigallocatechin (EGC), myricetin (ME), and phloridzin (PHZ)

\begin{tabular}{|c|c|c|c|c|c|c|c|}
\hline \multirow[b]{2}{*}{ Variables } & \multicolumn{7}{|c|}{$F$ values $^{z}$} \\
\hline & IT & PI & ET & $\mathbf{I T} \times \mathbf{P I}$ & $\mathbf{I T} \times \mathbf{E T}$ & $\mathbf{P I} \times \mathbf{E T}$ & $\mathbf{I T} \times \mathbf{P I} \times \mathbf{E T}$ \\
\hline TBR & $111.29 *$ & $432.14 * *$ & $1.84^{\mathrm{ns}}$ & $51.04 *$ & $43.09 *$ & $262.90 * *$ & $277.41 * *$ \\
\hline 7-MX & $16.06 * *$ & $371.59 * *$ & $68.95 * *$ & $3.55^{*}$ & $9.47 * *$ & $26.19 *$ & $6.30 *$ \\
\hline PCA & $17.69 * *$ & $33.88^{* *}$ & $820.62 * *$ & $14.56^{* *}$ & $16.25 * *$ & $31.94 * *$ & $13.29 * *$ \\
\hline $\mathrm{SA}$ & $291.71 * *$ & $12.27^{*}$ & $3549.24 * *$ & $47.41^{*}$ & $275.93^{* *}$ & $1474.83^{* * *}$ & $41.99 *$ \\
\hline GA & $4.93 *$ & $173.26 * *$ & $58.44^{*}$ & $6.07 *$ & $7.34^{*}$ & $21.73^{*}$ & $8.14^{*}$ \\
\hline PHB & $70.73 * *$ & $199.48 * *$ & $244.23 * *$ & $6.378^{*}$ & $65.54 * *$ & $13.679 *$ & $103.16^{* *}$ \\
\hline SHAM & $3.07 *$ & $365.59 * *$ & $427.24 * *$ & $0.88^{\mathrm{ns}}$ & $9.71 *$ & $6.59 *$ & $16.51 *$ \\
\hline CAT & $80.70 * *$ & $606.51 * *$ & $722.11 * *$ & $8.134 *$ & $40.59 * *$ & $8.477 *$ & $12.874 *$ \\
\hline EC & $9.44 *$ & $278.52 * *$ & $234.22 * *$ & $36.31 *$ & $16.89 *$ & $33.66^{*}$ & $17.52 *$ \\
\hline EGC & $13.86 *$ & $162.68 * *$ & $408.77 * *$ & $22.20 *$ & $20.52 *$ & $75,903 * *$ & $38.38 *$ \\
\hline $\mathrm{ME}$ & $17.80 *$ & $2566.77 * *$ & $92.76^{* *}$ & $17.80 *$ & $12.38^{*}$ & $92.76^{* *}$ & $12.38 *$ \\
\hline PHZ & $300.80 * *$ & $216.90 * *$ & $1130.66 * *$ & $80.11^{*}$ & $85.45 * *$ & $201.66^{* *}$ & $35.87 *$ \\
\hline
\end{tabular}

$\mathrm{z}$ Levels of probability: $\mathrm{ns}=$ not significant, $*=0.05$, and $* *=0.01$.

Table 3. Concentrations of alkaloids ( $\mu \mathrm{g} / \mathrm{mg}$ dry weight) in the stem tissues of mango plants sprayed with distilled water (control), acibenzolar-S-methyl (ASM), or potassium phosphite (Phi) and noninoculated (NI) or inoculated (I) with Ceratocystis fimbriata at three different evaluation times ${ }^{\mathrm{z}}$

\begin{tabular}{|c|c|c|c|c|c|c|c|}
\hline \multirow[b]{2}{*}{ Alkaloids } & \multirow[b]{2}{*}{ Treatments } & \multicolumn{3}{|c|}{ NI } & \multicolumn{3}{|c|}{ I } \\
\hline & & 7 dai & 14 dai & 21 dai & 7 dai & 14 dai & 21 dai \\
\hline \multirow[t]{3}{*}{ Theobromine } & Control & $3.89 \mathrm{bB}$ & $6.06 \mathrm{aA}$ & $1.56 \mathrm{cB}$ & 1.49 bB* & $1.34 \mathrm{bB} *$ & $3.13 \mathrm{aB} *$ \\
\hline & ASM & $7.59 \mathrm{aA}$ & $5.09 \mathrm{bB}$ & $1.95 \mathrm{cB}$ & $1.59 \mathrm{bAB}^{*}$ & $1.34 \mathrm{bB}^{*}$ & $9.05 \mathrm{aA}^{*}$ \\
\hline & $\mathrm{Phi}$ & $4.29 \mathrm{bB}$ & $3.77 \mathrm{bC}$ & $5.45 \mathrm{aA}$ & $1.79 \mathrm{bA}^{*}$ & $2.21 \mathrm{aA}^{*}$ & $0.00 \mathrm{cC}^{*}$ \\
\hline \multirow{3}{*}{ 7-Methylxanthine } & Control & $1.02 \mathrm{aB}$ & $1.10 \mathrm{aB}$ & $0.83 \mathrm{bB}$ & $0.63 \mathrm{aA}^{*}$ & $0.59 \mathrm{aB} *$ & $0.00 \mathrm{bA}^{*}$ \\
\hline & ASM & $1.45 \mathrm{aAB}$ & $0.85 \mathrm{bB}$ & $1.35 \mathrm{aA}$ & $0.65 \mathrm{aA}^{*}$ & $0.69 \mathrm{aB}^{*}$ & $0.00 \mathrm{bA}^{*}$ \\
\hline & Phi & $1.63 \mathrm{aA}$ & $1.48 \mathrm{aA}$ & $0.96 \mathrm{bB}$ & $0.70 \mathrm{bA}^{*}$ & $0.99 \mathrm{aA}^{*}$ & $0.00 \mathrm{cA}^{*}$ \\
\hline
\end{tabular}

${ }^{\mathrm{z}}$ For the NI and I treatments, means within a column followed by the same uppercase letter or means within a row followed by the same lowercase letter are not significantly different $(P \leq 0.05)$ as determined by Tukey' test. Asterisk $(*)$ indicates significant difference between the NI and I treatments for each inducer and control treatment at each evaluation time. dai $=$ days after inoculation. 
Regardless of the treatment, the concentrations of catechin, epigallocatechin, myricetin, and phloridzin were commonly higher in the stem tissues of the inoculated plants than in the stem tissues of the noninoculated plants, while the inverse was observed for epicatechin (Table 6). Higher concentrations of catechin, epicatechin, epigallocatechin, myricetin, and phloridzin were detected at 14 and 21 dai in the stem tissues of the noninoculated or inoculated plants sprayed with water, ASM, or Phi (Table 6).

\section{Discussion}

The results from the present study support previous findings that secondary metabolites are involved in the resistance of mango plants to $C$. fimbriata infection $(4,5)$. The present study is the first to describe, to the best of the authors' knowledge, the defense responses associated with induced resistance of mango plants to $C$. fimbriata infection at both microscopic and biochemical levels.

Spraying the plants with ASM or Phi reduced the internal necrosis and the AUURLLPC, AUDRLLPC, and AURFCPC values, thus indicating their potential to increase resistance to $C$. fimbriata infection in mango plants. Several studies have demonstrated that ASM and Phi can increase the resistance of many wood plants to different diseases $(13,18,38,42,61)$. ASM and Phi also have been used to protect plants against pathogens capable of colonizing xylem such as $F$. oxysporum f.sp. radicis-lycopersici (8), Thielaviopsis basicola (35), and Verticillium dahlia $(15,37,42)$. Thus, induced resistance seemed a promising strategy to control mango wilt.

Stronger autofluorescence was noticed in the cells proximal to the internal necrotic areas in the sections obtained from the plants sprayed with ASM or Phi than in the tissues of the plants from the inoculated control treatment. Araujo et al. (5) also found similar results in the stem sections from resistant mango cultivars to $C$. fimbriata infection. This type of defense reaction has been reported in the literature as barrier zones that are impregnated with suberin, lignin, and phenolic-like compounds and contribute to reducing the spread of the pathogens $(3,10,11,23,44)$. Induced synthesis of secondary metabolites by previous treatment with ASM and Phi has been reported at microscopic level in several plant species following attack by different pathogens $(8,9,19,22,51)$. In the present study, the strong autofluorescence in response to $C$. fimbriata infection around the necrotic stem tissue observed in the plants sprayed with ASM or Phi is most likely to be due to barrier zones infused with secondary metabolites. The induction of these compounds can help to prevent fungal spread through the vascular system and other cells, as indicated by reduced levels of disease symptoms.

The fungal hyphae apparently grew without any impedance in the cells of the stem tissues of the plants from the control treatment. In contrast, in the stems of plants treated with ASM or Phi, most cells reacted to $C$. fimbriata infection by accumulating phenolic-like compounds (indicated by dark blue or purple colors), which contributed to many fungal hyphae appearing dead. Araujo et al. $(4,5)$ also reported the occurrence of empty fungal hyphae of $C$. fimbriata surrounded by amorphous material in the cells of resistant mango cultivars. Normally, ASM and Phi induce rapid and localized defense responses in susceptible plants that are similar to those observed in a race-specific resistance $(2,19,22,51)$. Benhamou and Bélanger $(8,9)$ showed histopathological evidence that application of ASM sensitizes susceptible cucumber and tomato plants to react more rapidly and efficiently to $P$. ultimum and $F$. oxysporum f.sp. radicislycopersici attack, respectively, through the massive accumulation of phenolic-like compounds at sites of potential fungal entry. In the present study, the accumulation of phenolic-like compounds most likely contributed to diminishing the colonization by $C$. fimbriata in the cells and helped to explain the lower values for the AUURLLPC, AUDRLLPC, and AURFCP in plants treated with ASM and Phi.

Intense deposition of phenolic-like compounds in the parenchyma cells adjacent to the xylem vessels that were fully obstructed by large tyloses were often seen in the stem tissues of the plants sprayed with

Table 4. Concentrations of hydroxycinnamic acids ( $\mu \mathrm{g} / \mathrm{mg}$ dry weight) in the stem tissues of mango plants sprayed with distilled water (control), acibenzolar-Smethyl (ASM), or potassium phosphite (Phi) and noninoculated (NI) or inoculated (I) with Ceratocystis fimbriata at three different evaluation times ${ }^{\mathrm{z}}$

\begin{tabular}{|c|c|c|c|c|c|c|c|}
\hline \multirow[b]{2}{*}{ Hydroxycinnamic acids } & \multirow[b]{2}{*}{ Treatments } & \multicolumn{3}{|c|}{ NI } & \multicolumn{3}{|c|}{ I } \\
\hline & & 7 dai & 14 dai & 21 dai & 7 dai & 14 dai & 21 dai \\
\hline \multirow[t]{3}{*}{$p$-Coumaric acid } & Control & $9.66 \mathrm{aA}$ & $0.0 \mathrm{bA}$ & $0.0 \mathrm{bA}$ & $10.91 \mathrm{aC}^{*}$ & $0.0 \mathrm{bA}$ & $0.0 \mathrm{bA}$ \\
\hline & ASM & $10.64 \mathrm{aA}$ & $0.0 \mathrm{bA}$ & $0.0 \mathrm{bA}$ & $12.76 \mathrm{aB}^{*}$ & $0.0 \mathrm{bA}$ & $0.0 \mathrm{bA}$ \\
\hline & Phi & $10.53 \mathrm{aA}$ & $0.0 \mathrm{bA}$ & $0.0 \mathrm{bA}$ & $22.31 \mathrm{aA}^{*}$ & $0.0 \mathrm{bA}$ & $0.0 \mathrm{bA}$ \\
\hline \multirow[t]{3}{*}{ Sinapinic acid } & Control & $36.33 \mathrm{aA}$ & $0.0 \mathrm{bA}$ & $0.0 \mathrm{bA}$ & $20.74 \mathrm{aB}^{*}$ & $10.46 \mathrm{bA}^{*}$ & $3.00 \mathrm{cC}^{*}$ \\
\hline & ASM & $37.71 \mathrm{aA}$ & $0.0 \mathrm{bA}$ & $0.0 \mathrm{bA}$ & $24.95 \mathrm{aA}^{*}$ & $9.37 \mathrm{bA}^{*}$ & $8.89 \mathrm{bA}^{*}$ \\
\hline & $\mathrm{Phi}$ & $26.39 \mathrm{aB}$ & $0.0 \mathrm{bA}$ & $0.0 \mathrm{bA}$ & $0.00 \mathrm{cC}^{*}$ & $9.47 \mathrm{aA}^{*}$ & $6.27 \mathrm{bB} *$ \\
\hline
\end{tabular}

${ }^{\mathrm{z}}$ For the NI and I treatments, means within a column followed by the same uppercase letter or means within a row followed by the same lowercase letter are not significantly different $(P \leq 0.05)$ as determined by Tukey' test. Asterisk $\left(^{*}\right)$ indicates significant difference between the NI and I treatments for each inducer and control treatment at each evaluation time. dai = days after inoculation.

Table 5. Concentrations of hydroxybenzoic acids ( $\mu \mathrm{g} / \mathrm{mg}$ dry weight) in the stem tissues of mango plants sprayed with distilled water (control), acibenzolar-Smethyl (ASM), or potassium phosphite (Phi) and noninoculated (NI) or inoculated (I) with Ceratocystis fimbriata at three different evaluation times ${ }^{\mathrm{Z}}$

\begin{tabular}{|c|c|c|c|c|c|c|c|}
\hline \multirow[b]{2}{*}{ Hydroxybenzoic acids } & \multirow[b]{2}{*}{ Treatments } & \multicolumn{3}{|c|}{ NI } & \multicolumn{3}{|c|}{$\mathbf{I}$} \\
\hline & & 7 dai & 14 dai & 21 dai & 7 dai & 14 dai & 21 dai \\
\hline \multirow[t]{3}{*}{ Gallic acid } & Control & $0.93 \mathrm{cB}$ & $1.86 \mathrm{aA}$ & 1.26 bB & $0.60 \mathrm{cA}^{*}$ & $0.95 \mathrm{bA}^{*}$ & $1.14 \mathrm{aB}$ \\
\hline & ASM & $1.43 \mathrm{aA}$ & $1.31 \mathrm{aB}$ & $1.47 \mathrm{aAB}$ & $0.62 \mathrm{cA}^{*}$ & $0.96 \mathrm{bA}^{*}$ & $1.32 \mathrm{aA}$ \\
\hline & Phi & $1.11 \mathrm{cB}$ & $2.25 \mathrm{aA}$ & $1.61 \mathrm{bA}$ & $0.61 \mathrm{cA}^{*}$ & $0.86 \mathrm{bA}^{*}$ & $1.25 \mathrm{aAB}^{*}$ \\
\hline \multirow[t]{3}{*}{$p$-Hydroxybenzoic acid } & Control & $0.00 \mathrm{bC}$ & $0.00 \mathrm{bB}$ & $2.55 \mathrm{aA}$ & $2.29 \mathrm{aA}^{*}$ & $2.10 \mathrm{aA}^{*}$ & $1.17 \mathrm{bB} *$ \\
\hline & ASM & $2.68 \mathrm{aA}$ & $1.60 \mathrm{bA}$ & $1.08 \mathrm{cB}$ & $2.52 \mathrm{bA}$ & $1.74 \mathrm{bA}$ & $5.10 \mathrm{aA} *$ \\
\hline & Phi & $2.09 \mathrm{bB}$ & $0.00 \mathrm{cB}$ & $2.98 \mathrm{aA}$ & $2.31 \mathrm{bA}$ & $0.00 \mathrm{cB}$ & $4.97 \mathrm{aA}^{*}$ \\
\hline \multirow[t]{3}{*}{ Salicylhydroxamic acid } & Control & $4.27 \mathrm{cB}$ & $15.99 \mathrm{bA}$ & $20.51 \mathrm{aA}$ & $12.75 \mathrm{cB}^{*}$ & $25.83 \mathrm{aA}^{*}$ & 19.47 bB \\
\hline & ASM & $6.98 \mathrm{bA}$ & $16.07 \mathrm{aA}$ & $17.15 \mathrm{aB}$ & $14.50 \mathrm{bA}^{*}$ & $21.28 \mathrm{aB}^{*}$ & $24.70 \mathrm{aA}^{*}$ \\
\hline & Phi & $7.23 \mathrm{cA}$ & $15.78 \mathrm{bA}$ & $19.34 \mathrm{aAB}$ & $13.46 \mathrm{cB}^{*}$ & $21.83 \mathrm{bB}^{*}$ & $26.93 \mathrm{aA}^{*}$ \\
\hline
\end{tabular}

${ }^{\mathrm{z}}$ For the NI and I treatments, means within a column followed by the same uppercase letter or means within a row followed by the same lowercase letter are not significantly different $(P \leq 0.05)$ as determined by Tukey' test. Asterisk $(*)$ indicates significant difference between the NI and I treatments for each inducer and control treatment at each evaluation time. dai $=$ days after inoculation. 
ASM or Phi. Similar results were also reported by Araujo et al. (4), who observed that the formation of an antifungal barrier and quick deposition of tyloses impregnated with phenolic compounds in resistant mango plants contributed to impeding the colonization of the xylem vessels by $C$. fimbriata. The formation of antifungal barrier is an efficient defense mechanism for avoiding the colonization of the pathogens that cause wilt symptoms $(3,5,10,23,44)$. Tyloses are good examples of occluding structures produced by plants that also serve to impede tissue colonization by the pathogens that cause wilt symptoms, but they are effective whether produced before fungal ingress or at the beginning of the colonization process (11). In the present study, fungal hyphae rarely reached the xylem vessels of the plants sprayed with ASM or Phi, most likely due to the protective nature of the antifungal barrier. However, when fungal hyphae reached the xylem vessels of the plants with induced resistance, these also rapidly prevented the pathogen invasion by quick deposition of tyloses impregnated with phenolic compounds, which probably prevented the vertical colonization of the vessels by $C$. fimbriata.

The concentration of two alkaloids (theobromine and 7-methylxanthine), two hydroxycinnamic acids ( $p$-coumaric acid and sinapinic acid), three hydroxybenzoic acids (gallic acid, $p$-hydroxybenzoic acid, and salicylhydroxamic acid), and five flavonoids (catechin, epicatechin, epigallocatechin, myricetin, and phloridzin) in the stem tissues of the plants sprayed with ASM or Phi was higher than the concentrations of these compounds in the plants from the inoculated control treatment. The potentiation of the phenolic metabolism of plants has often been associated with the induced resistance phenomenon $(2,8,9,19,28,51)$. High concentrations of methylxanthines (caffeine), theobromine, ellagic acid, $p$-coumaric acid, gallic acid, and kaempferol in the tissues of cocoa and strawberries plants treated with ASM were linked to the induction of plant defense mechanisms against infection by Crinipellis perniciosa and S. macularis, respectively (2,28). Daniel and Guest (19) reported that Arabidopsis seedlings treated with Phi showed enhanced accumulation of phenolics around the cells infected by $P$. palmivora compared with control plants. It is known that the fungitoxic effect of most plant secondary metabolites is attributed to their interaction with lipids or an increase in the phospholipid concentration in the fungal cells (60). This in turn induces an increase in membrane permeability, leakage of cellular contents, and cytoplasm aggregation (60). In the present study, the data obtained at the microscopic level revealed an abundance of dead C. fimbriata hyphae surrounded by phenolic-like compounds in the cells of the stem tissues of the plants treated with ASM or Phi. These findings are consistent with the data obtained at biochemical level, which indicated that the concentrations of secondary metabolites were higher in the stem tissues of the plants treated with ASM or Phi, suggesting that they contribute to the reduction in mango wilt symptoms.

Regardless of the treatment, the concentrations of the phenolic compounds were higher in the stem tissues of the inoculated plants than in the stem tissues of the noninoculated ones, while the inverse was observed for alkaloids. Plants respond to physical injury, pathogen infection, abiotic and biotic elicitors, or different types of stress by increasing the concentration of pre-existing alkaloids and phenolics or by producing new ones through various metabolic pathways $(36,53)$. Thus, higher concentrations of secondary metabolites are often found in the tissues of plants infected by pathogens than in the tissues of noninfected plants $(2,28,45,48,51)$. However, higher concentrations of some secondary metabolites could be found in tissues of noninfected plants than in the infected ones based to disease development (59). In the present study, phenolics seemed to have been the most primordial compounds in coping with $C$. fimbriata infection in mango plants; they were more important than alkaloids, which accumulated at higher levels in the noninoculated plants.

Higher concentrations of secondary metabolites in the stem tissues were detected in the early stages of the fungal infection, especially in plants treated with inducers. Secondary metabolites are stored in the vacuoles of plant cells from where they can be rapidly infused after wounding, pathogen infection, abiotic and biotic elicitors, and other types of stress such as drought, extreme temperatures, and UV radiation $(36,53)$. The ability of plants to rapidly initiate the production of secondary metabolites may explain, at least in part, the final extent of the disease $(36,48,53,59)$. This finding explains in part why plants treated with ASM or Phi exhibited slower and reduced disease symptoms than plants from the control treatment.

Both microscopic and biochemical evidence from the present study clearly support the concept that the phenylpropanoid pathway can be induced by ASM and Phi in the stem tissues of plants infected by $C$. fimbriata. ASM and Phi induced many defense responses in the stem tissues of plants infected by $C$. fimbriata, such as accumulation of phenolic-like compounds, formation of an antifungal barrier, and quick deposition of tyloses impregnated with phenolics. Biochemically, it is possible to postulate that secondary metabolites such as catechin, epicatechin, epigallocatechin, gallic acid, myricetin, $p$-coumaric acid, $p$-hydroxybenzoic acid, phloridzin, sinapinic acid, salicylhydroxamic acid, theobromine, and 7-methylxanthine played important roles in the induced resistance of the mango plants to C. fimbriata infection. Taken together, the results indicated that induced resistance represents a promising control strategy to mango wilt.

Table 6. Concentrations of flavonoids ( $\mu \mathrm{g} / \mathrm{mg}$ dry weight) in the stem tissues of mango plants sprayed with distilled water (control), acibenzolar-S-methyl (ASM), or potassium phosphite (Phi) and noninoculated (NI) or inoculated (I) with Ceratocystis fimbriata at three different evaluation times ${ }^{\mathrm{z}}$

\begin{tabular}{|c|c|c|c|c|c|c|c|}
\hline \multirow[b]{2}{*}{ Flavonoids } & \multirow[b]{2}{*}{ Treatments } & \multicolumn{3}{|c|}{ NI } & \multicolumn{3}{|c|}{ I } \\
\hline & & 7 dai & 14 dai & 21 dai & 7 dai & 14 dai & 21 dai \\
\hline \multirow[t]{3}{*}{ Catechin } & Control & $0.00 \mathrm{bA}$ & $0.00 \mathrm{bB}$ & $1.66 \mathrm{aB}$ & $1.45 \mathrm{bA}^{*}$ & $2.96 \mathrm{aA}^{*}$ & $3.24 \mathrm{aB}^{*}$ \\
\hline & ASM & $0.00 \mathrm{cA}$ & $1.69 \mathrm{bA}$ & $3.90 \mathrm{aA}$ & $1.37 \mathrm{cA}^{*}$ & $2.62 \mathrm{bA} *$ & $5.64 \mathrm{aA}^{*}$ \\
\hline & Phi & $0.00 \mathrm{cA}$ & $1.45 \mathrm{bA}$ & $3.01 \mathrm{aA}$ & $1.25 \mathrm{cA}^{*}$ & $3.03 \mathrm{bA}^{*}$ & $5.79 \mathrm{aA}^{*}$ \\
\hline \multirow[t]{3}{*}{ Epicatechin } & Control & $3.29 \mathrm{aA}$ & $2.44 \mathrm{bA}$ & $3.33 \mathrm{aA}$ & $2.09 \mathrm{aB}^{*}$ & $1.89 \mathrm{aA}^{*}$ & $0.00 \mathrm{bB} *$ \\
\hline & ASM & $3.25 \mathrm{aA}$ & $2.01 \mathrm{bA}$ & $1.47 \mathrm{bA}$ & $3.15 \mathrm{aA}$ & $1.60 \mathrm{bA}^{*}$ & $1.11 \mathrm{cA}^{*}$ \\
\hline & Phi & $3.55 \mathrm{aA}$ & $2.34 \mathrm{bA}$ & $1.37 \mathrm{cA}$ & $2.08 \mathrm{aB}^{*}$ & $1.88 \mathrm{aA}^{*}$ & $0.00 \mathrm{bB}^{*}$ \\
\hline \multirow[t]{3}{*}{ Epigallocatechin } & Control & $0.00 \mathrm{cA}$ & $3.13 \mathrm{bA}$ & $5.19 \mathrm{aA}$ & $2.56 \mathrm{bA}^{*}$ & $5.76 \mathrm{aA}^{*}$ & $1.10 \mathrm{cB}^{*}$ \\
\hline & ASM & $0.00 \mathrm{cA}$ & $3.30 \mathrm{bA}$ & $4.39 \mathrm{aB}$ & $2.36 \mathrm{bA}^{*}$ & $5.46 \mathrm{aAB}^{*}$ & $5.90 \mathrm{aA}^{*}$ \\
\hline & Phi & $0.00 \mathrm{cA}$ & $3.43 \mathrm{bA}$ & $4.64 \mathrm{aAB}$ & $2.56 \mathrm{bA}^{*}$ & $4.86 \mathrm{aB}^{*}$ & $5.75 \mathrm{aA}^{*}$ \\
\hline \multirow[t]{3}{*}{ Myricetin } & Control & $0.00 \mathrm{aA}$ & $0.00 \mathrm{aA}$ & $0.00 \mathrm{aA}$ & $1.84 \mathrm{aA}^{*}$ & $1.48 \mathrm{bB}^{*}$ & $0.30 \mathrm{cB}^{*}$ \\
\hline & ASM & $0.00 \mathrm{aA}$ & $0.00 \mathrm{aA}$ & $0.00 \mathrm{aA}$ & $1.81 \mathrm{aA}^{*}$ & $1.74 \mathrm{abA} *$ & $1.32 \mathrm{bA}^{*}$ \\
\hline & Phi & $0.00 \mathrm{aA}$ & $0.00 \mathrm{aA}$ & $0.00 \mathrm{aA}$ & $1.61 \mathrm{aA}^{*}$ & $1.68 \mathrm{aAB}^{*}$ & $1.07 \mathrm{bA}^{*}$ \\
\hline \multirow[t]{3}{*}{ Phloridzin } & Control & $0.00 \mathrm{bA}$ & $0.00 \mathrm{bC}$ & $2.92 \mathrm{aC}$ & $0.00 \mathrm{cA}$ & $2.08 \mathrm{aB}^{*}$ & $0.83 \mathrm{bB} *$ \\
\hline & $\mathrm{ASM}$ & $0.00 \mathrm{cA}$ & $2.95 \mathrm{bB}$ & $4.14 \mathrm{aB}$ & $0.00 \mathrm{bA}$ & $2.53 \mathrm{aAB}^{*}$ & $2.10 \mathrm{aA}^{*}$ \\
\hline & Phi & $0.00 \mathrm{cA}$ & $4.86 \mathrm{bA}$ & $6.08 \mathrm{aA}$ & $0.00 \mathrm{cA}$ & $3.09 \mathrm{aA}^{*}$ & $2.38 \mathrm{bA}^{*}$ \\
\hline
\end{tabular}

${ }^{\mathrm{z}}$ For the NI and I treatments, means within a column followed by the same uppercase letter or means within a row followed by the same lowercase letter are not significantly different $(P \leq 0.05)$ as determined by Tukey' test. Asterisk $(*)$ indicates significant difference between the NI and I treatments for each inducer and control treatment at each evaluation time. dai $=$ days after inoculation. 


\section{Acknowledgments}

Profs. Fabrício A. Rodrigues and Sergio A. Fernandes thank CNPq for their fellowships. Dr. Leonardo Araujo was supported by CNPq. The authors thank Mr. Eduardo Rezende Pereira and Mr. Edvaldo Barros for their technical assistance. The authors thank Prof. Acelino C. Alfenas and Mr. Leonardo S. S. Oliveira for kindly providing the isolate of $C$. fimbriata used in this study. This study was supported by a grant from Vale S.A. to Prof. F. A. Rodrigues.

\section{Literature Cited}

1. Ajila, C. M., Rao, L. J., and Rao, U. J. S. P. 2010. Characterization of bioactive compounds from raw and ripe Mangifera indica L. peel extracts. Food Chem. Toxicol. 48:3406-3411.

2. Aneja, M., and Gianfagna, T. 2001. Induction and accumulation of caffeine in young, actively growing leaves of cocoa (Theobroma cacao L.) by wounding or infection with Crinipellis perniciosa. Physiol. Mol. Plant Pathol. 59:13-16.

3. Aoun, M., Rioux, D., Simard, M., and Bernier, L. 2009. Fungal colonization and host defense reactions in Ulmus americana callus cultures inoculated with Ophiostoma novo-ulmi. Phytopathology 99:642-650.

4. Araujo, L., Bispo, W. M. S., Cacique, I. S., Cruz, M. F. A., and Rodrigues, F. A. 2014. Histopathological aspects of mango resistance to the infection process of Ceratocystis fimbriata. Plant Pathol. 63:1282-1295.

5. Araujo, L., Bispo, W. M. S., Cacique, I. S., Moreira, W. R., and Rodrigues, F. A. 2014. Resistance in mango against infection by Ceratocystis fimbriata. Phytopathology 104:820-833.

6. Araujo, L., Borsato, L. C., Valdebenito-Sanhueza, R. M., and Stadnik, M. J. 2008. Fosfito de potássio e ulvana no controle da mancha foliar da gala em macieira. Trop. Plant Pathol. 33:148-152.

7. Araujo, L., Valdebenito-Sanhueza, R. M., and Stadnik, M. J. 2010. Avaliação de formulações de fosfito de potássio sobre Colletotrichum gloeosporioides in vitro e no controle pós-infeccional da mancha foliar de Glomerella em macieira. Trop. Plant Pathol. 35:54-59.

8. Benhamou, N., and Bélanger, R. R. 1998. Benzothiadiazole-mediated induced resistance to Fusarium oxysporum f.sp. radicis-lycopersici in tomato. Plant Physiol. 118:1203-1212.

9. Benhamou, N., and Bélanger, R. R. 1998. Induction of systemic resistance to Pythium damping-off in cucumber plants by benzothiadiazole: ultrastructure and cytochemistry of the host response. Plant J. 14:13-21.

10. Bishop, G. D., and Cooper, R. M. 1983. An ultrastructural study of root invasion in three vascular wilt diseases. Physiol. Plant Pathol. 22:15-27.

11. Blanchette, R. A., and Biggs, A. T. 1992. Defense Mechanisms of Woody Plants Against Fungi. Springer-Verlag, Berlin.

12. Boneti, J. I. S., and Katsurayama, Y. 2005. Viabilidade do uso de fosfitos no controle da sarna-da-macieira. Agrop. Catarinense 18:51-54.

13. Brisset, M. N., Cesbron, S., Thomson, S. V., and Paulin, J. P. 2000. Acibenzolar-S-methyl induces the accumulation of defense-related enzymes in apple and protects from fire blight. Eur. J. Plant Pathol. 106:529-536.

14. Carvalho, C. R. L., Rossetto, C. J., Mantovani, D. M. B., Morgano, M. A., Castro, J. V., and Bortoletto, N. 2004. Avaliação de cultivares de mangueira selecionadas pelo Instituto Agronômico de Campinas comparadas a outras de importância comercial. Rev. Bras. Frutic. 26:264-271.

15. Cavalcanti, L. S., and Resende, M. L. V. 2005. Efeito da época de aplicação e dosagem do acibenzolar-S-metil na indução de resistência à murcha-deVerticillium em cacaueiro. Fitopatol. Bras. 30:67-71.

16. Cohen, M. D., and Coffey, M. D. 1986. Systemic fungicides and the control of oomycetes. Annu. Rev. Phytopathol. 24:311-338.

17. Cushnie, T. P. T., and Lamb, A. J. 2005. Antimicrobial activity of flavonoids. Int. J. Antimicrob. Agents 26:343-356.

18. Dalio, R. J. D., Fleischmann, F., Humez, M., and Osswald, W. 2014. Phosphite protects Fagus sylvatica seedlings towards Phytophthora plurivora via local toxicity, priming and facilitation of pathogen recognition. PLoS ONE 9:e87860.

19. Daniel, R., and Guest, D. 2006. Defence responses induced by potassium phosphonate in Phytophthora palmivora-challenged Arabidopsis thaliana. Physiol. Mol. Plant Pathol. 67:194-201.

20. Dhingra, O. D., and Sinclair, J. B. 1995. Basic Plant Pathology Methods. Lewis Publisher, Boca Raton, FL.

21. Dixon, R. A., and Paiva, N. L. 1995. Stress induced phenylpropanoid metabolism. Plant Cell 7:1085-1097.

22. Eshraghi, L., Anderson, J., Aryamaneshd, N., Shearer, B., McComba, J., Hardya, G. E. St. J., and O'Brien, P. A. 2011. Phosphite primed defence responses and enhanced expression of defence genes in Arabidopsis thaliana infected with Phytophthora cinnamomi. Plant Pathol. 60: 1086-1095.

23. Eynck, C., Koopmann, B., Karlovsky, P., and von Tiedemann, A. 2009. Internal resistance in winter oilseed rape inhibits systemic spread of the vascular pathogen Verticillium longisporum. Phytopathology 99:802-811.

24. FAO. 2014. Medium-term prospects for agricultural commdities. Online: http://www.fao.org/docrep/006/y5143e/y5143e1a.htm

25. Förster, H., Adaskaveg, J. E., Kim, D. H., and Stanghellini, M. E. 1998. Effect of phosphite on tomato and pepper plants and on susceptibility of pepper to Phytophthora root and crown rot in hydroponic culture. Plant Dis. 82: 1165-1170.
26. Freeman, B. C., and Beattie, G. A. 2008. An overview of plant defenses against pathogens and herbivores. The Plant Health Instructor, 10.1094/ PHI-I-2008-0226-01.

27. Garba, S., and Okeniyi, S. O. 2012. Antimicrobial activities of total alkaloids extracted from some Nigerian medicinal plants. J. Microbiol. Antimicrob. 4: 60-63.

28. Hukkanen, A. T., Kokko, H. I., Buchala, A. J., Mcdougall, G. J., Stewart, D., Karenlampi, S. O., and Karjalainen, R. O. 2007. Benzothiadiazole induces the accumulation of phenolics and improves resistance to powdery mildew in strawberries. J. Agric. Food Chem. 55:1862-1870.

29. Junqueira, K. P., Faleiro, F. G., Uesugi, C. H., Junqueira, N. T. V., Bellon, G., Santos, E. C., and Ramos, L. N. 2011. Desempenho agronômico de maracujazeiros tratados com produtos alternativos e fertilizantes foliares. Rev. Bras. Frutic. 33:40-47.

30. Kaur, J., Rathinam, X., Kasi, M., Leng, L. M., Ayyalu, R., Kathiresan, S., and Subramaniam, S. 2010. Preliminary investigation on the antibacterial activity of mango (Mangifera indica L: Anacardiaceae) seed kernel. Asian Pac. J. Trop. Med. 3:707-710.

31. Knoester, M., Pieterse, C. M. J., Bol, J. F., and Van Loon, L. C. 1999 Systemic resistance in Arabidopsis induced by rhizobacteria requires ethylene-dependent signaling at the site of application. Mol. Plant Microbe Interact. 12:720-727.

32. Lisec, J., Schauer, N., Kopka, J., Willmitzer, L., and Fernie, A. R. 2006. Gas chromatography mass spectrometry-based metabolite profiling in plants. Nat. Protoc. 1:387-396.

33. Mazid, M., Khan, T. A., and Mohammad, F. 2011. Role of secondary metabolites in defense mechanisms of plants. Biol. Med. (Paris) 3: 232-249.

34. Métrauxs, J. P. 2001. Systemic acquired resistance and salicylic acid: current state of knowledge. Eur. J. Plant Pathol. 107:13-18.

35. Mondal, A. H., Nehl, D. B., and Allen, S. J. 2005. Acibenzolar-S-methyl induces systemic resistance in cotton against black root rot caused by Thielaviopsis basicola. Australas. Plant Pathol. 34:499-507.

36. Nicholson, R. L., and Hammerschmidt, R. 1992. Phenolic compounds and their role in disease resistance. Annu. Rev. Phytopathol. 30:369-389.

37. Pereira, R. B., Resende, M. L. V., Júnior, P. M. R., Amaral, D. R., Lucas, G. C., and Cavalcanti, F. R. 2008. Ativação de defesa em cacaueiro contra a murcha-de-Verticílio por extratos naturais e acibenzolar-S-metil. PAB 43: 171-178.

38. Reuveni, M., and Reuveni, R. 1995. Efficacy of foliar sprays of phosphates in controlling powdery mildews in field-grown nectarine, mango trees and grapevines. Crop Prot. 14:311-314.

39. Reuveni, M., Harpaz, M., and Reuveni, R. 1998. Integrated control of powdery mildew on field-grown mango trees by foliar sprays of monopotassium phosphate fertilizer, sterol inhibitor fungicides and the strobilurin Kresoxym-methyl. Eur. J. Plant Pathol. 104:853-860.

40. Ribeiro, I. J. A. 2005. Doenças da mangueira (Mangifera indica L.). Pages 457-465 in: Manual de Fitopatologia: Doenças das Plantas Cultivadas. H. Kimati, L. Amorim, A. Bergamin-Filho, L. E. A. Camargo, and J. A. M. Rezende, eds. Agronômica Ceres, São Paulo.

41. Ribeiro, I. J. A., Rossetto, C. J., Sabino, J. C., and Gallo, P. B. 1986. Seca da mangueira: VIII. Resistência de porta-enxertos de mangueira ao fungo Ceratocystis fimbriata Ell. \& Halst. Bragantia 45:317-322.

42. Ribeiro, P. M., Júnior, Resende, M. L. V., Pereira, R. B., Cavalcanti, F. R. Amaral, D. R., and Pádua, M. A. 2006. Fosfito de potássio na indução de resistência a Verticillium dahliae Kleb em mudas de cacaueiro (Theobroma cacao L.). Ciênc. Agrotec. 30:629-636.

43. Ribeiro, S. M. R., Barbosa, L. C. A., Queiroz, J. H., Knodler, M., and Schieber, A. 2008. Phenolic compounds and antioxidant capacity of Brazilian mango (Mangifera indica L.) varieties. Food Chem. 110: 620-626.

44. Rioux, D., and Baayen, R. P. 1997. A suberized perimedullary reaction zone in Populus balsamifera novel for compartmentalization in trees. Trees (Berl.) 11: 389-403.

45. Rodrigues, F. A., Benhamou, N., Datnoff, L. E., Jones, J. B., and Bélanger, R. R. 2003. Ultrastructural and cytochemical aspects of silicon-mediated rice blast resistance. Phytopathology 93:535-546.

46. Rossetto, C. J., Ribeiro, I. J. A., Igue, T., and Gallo, P. B. 1996. Seca-damangueira XV. Resistência varietal a dois isolados de Ceratocystis fimbriata. Bragantia 55:117-121.

47. Ryals, J., Uknes, S., and Ward, E. 1994. Systemic acquired resistance. Plant Physiol. 104:1109-1112.

48. Scarpari, L. M., Meinhardt, L. W., Mazzafera, P., Pomella, A. W. V., Schiavinato, M. A., Cascardo, J. C. M., and Pereira, G. A. G. 2005. Biochemical changes during the development of witches' broom: the most important disease of cocoa in Brazil caused by Crinipellis perniciosa. J. Exp. Bot. 56:865-877.

49. Shaner, G., and Finney, R. E. 1980. The effect of nitrogen fertilization on the expression of slow-mildewing resistance in knox wheat. Phytopathology 70: 1183-1186.

50. Smillie, R., Grant, B. R., and Guest, D. 1989. The mode of action of phosphite: evidence for both direct and indirect modes of action on three Phytophthora spp. in plants. Phytopathology 79:921-926. 
51. Stadnik, M. J., and Buchenauer, H. 2000. Inhibition of phenylalanine ammonia-lyase suppresses the resistance induced by benzothiadiazole in wheat to Blumeria graminis f.sp. tritici. Physiol. Mol. Plant Pathol. 57:25-34.

52. Tohge, T., and Fernie, A. R. 2010. Combining genetic diversity, informatics and metabolomics to facilitate annotation of plant gene function. Nat. Protoc. 5:1210-1227.

53. Treutter, D. 2005. Significance of flavonoids in plant resistance and enhancement of their biosynthesis. Plant Biol. 7:581-591.

54. Vallad, G. E., and Goodman, R. M. 2004. Systemic acquired resistance and induced systemic resistance in conventional agriculture. Crop Sci. 44:1920-1934.

55. van Loon, L. C., Rep, M., and Pieterse, C. M. J. 2006. Significance of inducible defense-related proteins in infected plants. Annu. Rev. Phytopathol. 44:135-162.

56. Van Wyk, M., Al Adawi, A. O., Khan, I. A., Deadman, M. L., Al Jahwari, A. A., Wingfield, B. D., Ploetz, R., and Wingfield, M. J. 2007. Ceratocystis manginecans sp. nov., causal agent of a destructive mango wilt disease in Oman and Pakistan. Fungal Divers. 27:213-230.

57. Vermerris, W., and Nicholson, R. 2006. Phenolic compound biochemistry. Springer, Dordrecht, The Netherlands.

58. Viégas, A. P. 1960. Seca da mangueira. Bragantia 19:163-182.

59. Wallis, C. M., and Chen, J. 2012. Grapevine phenolic compounds in xylem sap and tissues are significantly altered during infection by Xylella fastidiosa. Phytopathology 102:816-826.

60. Weete, E. R. 1980. Lipid Biochemistry of Fungi and Other Organisms. Plenum Press, New York.

61. Zainuri, D. E., Joyce, D. C., Wearing, A. H., Coates, L., and Terry, L. 2001 Effects of phosphonate and salicylic acid treatments on anthracnose disease development and ripening of 'Kensington Pride' mango fruit. Aust. J. Exp. Agric. 41:805-813. 